\title{
The Relationship Between the Curriculum of Higher Education and Social Capital
}

\author{
Forouzan Tonkaboni (Corresponding author)
}

PH.D. student, Department of Educational Science, Khorasgan (Isfahan) Branch, Islamic Azad University, Isfahan, Iran, E-mail: ftonkaboni@gmail.com

\begin{abstract}
Alireza Yousefy
Associate professor, Medical Education Research Center, Isfahan University of Medical Science, Isfahan, Iran
\end{abstract}

Narges Keshtiaray

Assistant professor, Department of Educational Science, Khorasgan (Isfahan) Branch, Islamic Azad University, Isfahan, Iran

Received: October 29, 2013 Accepted: November 13, 2013 Published: November 30, 2013

doi:10.5296/jet.v1i1.4599 URL: http://dx.doi.org/10.5296/jet.v1i1.4599

\begin{abstract}
This study analyzes the relationship between curriculum for higher education system and social capital. For this purpose, 150 subjects were selected by randomized sampling method using correlation method. Participants completed researcher-made questionnaire of curriculum and social capital. Validity and reliability coefficients of questionnaires, calculated by retest and Cronbach's alpha coefficient, were 0.40 and 0.50 , respectively. Research findings suggest that there was a significant and negative relation between scientific-educational objectives of curriculum and social participation but positive relation with social trust. However, there was a significant and positive relation between social and economic objectives of curriculum and social participation and negative relation with social trust. Further, there is a significant and positive relation between need assessment and social participation and trust.
\end{abstract}

Keywords: higher education, curriculum, social capital 


\section{Introduction}

Establishment and cohesion of a society, precisely depend upon performance of its modern institutions in maintenance and development of cultural heritage as well as responsibility in solving problems of present and future. Accordingly the educational institutions like schools and universities highlight operational pre-requisites of their community at time of determining goals, content, and teaching and learning methods in the curriculums .the educational institutions must offer required backgrounds for their members in relation to making correct relations with the environment, communicating with other individuals, quality of their society, and ways of playing roles in their society as well. According to Inglehart, Putnam and Burnheim, preparing these conditions causes a sort of positive individuals' participation in their world around including city and near and far villages (Yar Mohammadian, 2012).

During its short life, the concept of curriculum has beard several changes. The educational scholars believe that a curriculum consists of specification of the content of program, what should be learned, materials related to students, school experiences, different lesson topics for a year or an educational period, outline of educational objectives as well as course titles and headings . On the other hand, curriculum is known as planned and directed learning experienced are designed under guidance and surveillance of the educational environment and through rational reconstruction of knowledge and experiences seeks to permanent development of the learner in different persona and social areas (Alagheband, 2008).

The curriculum functions to define a series of expected goals and/or outcomes of learning in advance. In other words, curriculum is a set of opportunities for learners to get engaged with other individuals, and things in specific time and place. The curriculum, in fact, is a guide for teaching besides an organized sequence of expected learning outcomes. The curriculum defines teaching results. Prescription and description of learning materials and activities are essential for reaching the desired outcomes relate to domain of education .However, realizing the curriculum as a series of educational goals is a narrow understanding. Objectives are guidelines for any curriculum that should be taken into consideration for training the force is demanded by the society (Sharepour, 2004).

Schooling as a process aims to education or economic change the learner. This change could be in knowledge, attitude or in social, educations or economic performances (Saif, 2009).

In the curriculum, one of the chief processes is need assessment in the designing stage. In new approaches, the need assessment is regarded not only as a static phenomenon but also as a process. It is a pluralistic, flexible and based on the equal consideration principle in a way that in decision-making stage, in addition to conserving national principles and regulations, the local and rational needs are also counted.

These needs are primary resources in need assessment. In other words, in a final analysis, three factors of society, learner and course topics. But, because each if these materials tends to paradoxical ideologies, some tensions and conflicts are created among advocates of each material to be used in decisions related to curriculum design. (Mehr Mohammadi, 2010).

On the other hand, need analysis is incremental, responsive, meta responsive and realistic 
process. That is, the increasing characteristic of curriculum need analysis relies on degree of specification and intelligibility of needs in every level of need assessment. Need analysis is responsive only when it involves in defining and description of preplanned purposes in the curriculum due to designing need analysis study. The meta-responsive nature of need analysis implies that educational objectives could be produced through need analysis procedure. Also, in the need analysis process, information must be prepared useful for development and execution of the curriculum. In a way that, the provided information have to be appropriate and simultaneously gives a clear picture of the existing reality in the level the curriculum will be developed or implemented. Need analysis in a broader level above lesson topics, places in the framework of the Higher Council of Education or any other center is nationally responsible for curriculum design. Effective management of this process and the duties cause the social capital to expand in accordance with the current needs of society and the world either. The consequence of this process, therefore will be educating learners as social capitals of a society (Mehr Mohammadi, 2010).

Social capital is one of the most important indexes of growth and development in each society that incorporates such concepts as trust, cooperation, and empathy among member of a community that has established a purposeful system, which directs them toward achieving their valuable goals (Bourdieu, 2007).

According to the World Bank, social capital is a phenomenon raised by the impact of social institutions, human relations and norms, and quantity and quality of social interactions, which in turn considerably affect economy and development in all countries. Unlike other capitals, social capital has no physical entity, but it is the outcome of group and social communications. On the other hand, any increase in social capital leads to significant decrease in costs of society and operational costs of organizations (Woolcock, 2001).

A majority of scholars believe that social capital consists of several components like social trust, social solidarity and social participation. Social trust is essential for formation of social ties and interactions as well as cooperation and empathy. Social trust is considered as one of principal pre-requisites of social participation. Increase of social distrust, then reduces rate of social commitments, social participation and increase of social problems is a variable of decrease in social capital (Vahida, 2007).

Social participation refers to an organized process is performed by individuals consciously, voluntarily or in group that follow specific goals in order to share the sources of power. Number and expansion of local and non-governmental organization in a community signifies rate of social participation in that society (Field, 2007).

Therefore, according to the purpose of the present research, determination of the relationship between higher education systems with social capital, it sounds like education as one of powerful producers of social capital plays its role. The higher education students, through creation of necessary knowledge and skills directly via establishment of networks (in-group capital) and reinforcement of ties between groups (within group capital), contribute to production and storage of social capital. Through strengthening trust and participation among different groups (among group social capital) connect them together and causes an interaction 
between identities and learning from each other. The process of education creates a kind of new socialization, which brings about modern social connections and ends to reinforcement of students' social capital (Zaker Salehi, 2008).

Accordingly the purpose of this research is to determine the relationship between the higher education curriculums with social capital among the university graduates, the following research hypotheses are:

1. There is any relationship between objectives of higher education curriculum and social participation of graduates.

2. There is any relationship between objectives of higher education curriculum and social trust of graduates.

3. There is any relationship between need assessment of higher education curriculum and social participation of graduates.

4. There is any relationship between need assessment of higher education curriculum and social participation of graduates.

\section{Method}

The main purpose of the current study is to examine the relationship between the higher education and social capital among graduates. Accordingly, to measure the research variable, a researcher-made questionnaire for curriculum and the social capital survey based on Likert scale were used. Each questionnaire consisted of 20 items. The curriculum questionnaire included items about purpose of educational objectives (scope of knowledge, skill and attitude)and in social purposes like (responsibilities against family, friends, and neighbors, loving others, conserving others' rights, conserving rules, appreciating others and tolerance of opposite ideas ), in economic purposes items such as (respecting for others' ownership, interest in working, interest in consuming national productions, protecting public properties, distinguishing personal and others' ownership, and identification of careers) and finally for need assessment section (significance of need assessment, concept of need assessment, purpose of need assessment and information resources in need assessment) (UNESCO, 1999).

In the social capital questionnaire, items about rate and type of participation in social institutions and the graduates' trust to their society were included. The questionnaires reliability was measured via Cronbach alpha up to 0.40 and 0.50 respectively.This research conducted 0n May in 2013. The population consisted of all B.A. graduates of psychology, sociology, and Persian literature of Islamic Azad University at Central Tehran branch in 2012. Through random sampling method, 150 subjects were selected. After the questionnaires were collected, the data were analyzed by descriptive and inferential (correlation) statistics.

\section{Findings}

The findings indicate that the highest frequency (F: 54) is for psychology and the lowest frequency (F:47) for Persian literature. Table 1 shows distribution and percentage for different majors. 
Table 1. frequency of distribution and percentage of majors in the study group

\begin{tabular}{|l|l|l|}
\hline major & frequency & percent \\
\hline Persian literature & 47 & $31.33 \%$ \\
\hline sociology & 49 & $32.66 \%$ \\
\hline psychology & 54 & $36 \%$ \\
\hline total & 150 & $100 \%$ \\
\hline
\end{tabular}

Pearson's correlation coefficients were used to measure the relationship between factors of curriculum and factors of social capital.

Table 2. relationship between factors of curriculum with factors of social capital

\begin{tabular}{|c|c|c|c|c|}
\hline & & $\begin{array}{l}\text { Social } \\
\text { participation }\end{array}$ & $\begin{array}{l}\text { Social } \\
\text { trust }\end{array}$ & $\begin{array}{l}\text { Total social } \\
\text { capital }\end{array}$ \\
\hline \multirow[t]{2}{*}{$\begin{array}{l}\text { Scientific } \\
\text { purposes }\end{array}$} & $\begin{array}{l}\text { Pearson's correlation } \\
\text { coefficient }\end{array}$ & $035 .-0$ & $611 * * .0$ & $514 * * .0$ \\
\hline & significance & 179.0 & 000.0 & 002.0 \\
\hline \multirow[t]{2}{*}{ Social purposes } & $\begin{array}{l}\text { Pearson's correlation } \\
\text { coefficient }\end{array}$ & 031.0 & $060 .-0$ & 191.-0 \\
\hline & significance & 145.0 & 221.0 & 081.0 \\
\hline \multirow[t]{2}{*}{$\begin{array}{l}\text { Economic } \\
\text { purposes }\end{array}$} & $\begin{array}{l}\text { Pearson's correlation } \\
\text { coefficient }\end{array}$ & $354 * * .0$ & $279 .-0$ & 097.0 \\
\hline & significance & 011.0 & $0 / 256$ & 052.0 \\
\hline \multirow[t]{2}{*}{$\begin{array}{l}\text { Need } \\
\text { assessment }\end{array}$} & $\begin{array}{l}\text { Pearson's correlation } \\
\text { coefficient }\end{array}$ & $290 * * .0$ & 105.0 & 131.0 \\
\hline & significance & 020.0 & 121.0 & 231.0 \\
\hline
\end{tabular}

** in 0.01 level of significance is meaningful. 
The results show that there is a meaningful and negative relationship between scientific-educational objectivesof curriculum with social participation (r:-0.035, P: 0.000). But there is a positive and meaningful relationship between scientific-educational objectivesof curriculum with social trust (r: 0.611, P: 0.01). A positive and meaningful relationship was observed between social objectivesof curriculum with participation (r: 0.031, P: 0.01). Though, a negative and meaningful relationship was identified between social objectivesand social trust (r: -0.060, P: 0.010).

Moreover, a meaningful and positive relationship was found between economic purposes of curriculum with social participation with known peoples (r: $0.345, \mathrm{P}: 0.01$ ), but a negative and meaningful relationship between economic purposes and social trust to unknown peoples (r: $0.279, \mathrm{P}: 0.01$ ). Also, there is a positive and meaningful relationship between need assessment of curriculum with social trust (r: 0.105, P: 0.01) and social participation (r: 0.29, P: 0.01).

\section{Discussion and Conclusion}

In the current research the relationship between purposes and need assessment of curriculum with social capital (social participation and trust) showed that there is a meaningful relationship between purpose and need assessment of curriculum, with social capital. In other words, there is a relationship between scientific-educational objectivesof curriculum with social participation and social trust. The educational-scientific purposes of curriculum in the higher education system has decreased rate of social participation among graduates. There is a meaningful relationship between social objectives of curriculum with participation and social trust. In other words, social objectivesof curriculum have slightly increased social participation among graduates. But, these purposes have reduced social trust in the society. Moreover, a meaningful relationship was found between economic purposes of curriculum with social participation and social trust. In other words, economic purposes have increased social participation of graduates in economic affairs with known persons. Though, they decreased the individuals' trust to each other in group work. Also, there is a meaningful relationship between need assessment of curriculum with social participation and trust. In other words, need assessment of curriculum to some extent has increased social trust and participation of graduates. These findings have some agreement and disagreement with a few other studies.

Chalabi (2007), Inglehurt (2003) and Woolcock (2008) found that although having physical, material and human capital have made quantitative development possible for achievement of quantitative development and solving different problems, attention to social capital greatly matters.

Several studies about social capital in Iran showed low rate of social participation. According to indexes and components of social capital, rate of familiarity, participation and social trust in Iran is not in an acceptable level. If the relationship between social capital and education problems like designed curriculum bear no experimental analysis, significance of any research in this area becomes critical. Such level of social capital causes to many problems (Mohseni, 1998; Mousavi Khameneh, 2005; Firouz Abadi, 2005; Chalbi, 2005; and Piran, 2006). 
Mourfi and Dolan (2003), in their study on social participation and the impact of increase of educational average, increase social trust and social participation and people with higher education posses high rate of social participation and in crisis contribute more to others and are more willing to get progressed in collective activities .

Grayson (2004); Flick and Williason (2005); and Totterman and Wulff (2007) stated that social networks based on educational environments affect attitudes on professional opportunities, access to information and interaction with other students and has a great share in different sectors, local connected networks and foreign networks and social capital (social participation and trust) are related to educational achievements, innovation in education and time of education at university and diversity in educational methods causes social capital to increase like group learning and learning of services.

Park (2006) in the investigation on the role of trust in development of knowledge understood that existence of social capital are of major condition for individuals' opportunity, motivation and capability and social trust is highly effective on creation of knowledge trough capability of accumulating knowledge and motivation and factors like formal networks, education, and informal networks, common norms and values .

On the other hand, examination of relationship between higher education and social capital indicate that in Iran the educated persons are transiting from traditional to modernism. Also, the educational system and level of socialization of learners (social participations) are in low degree and the higher education institutions only pay attention to educational aspect in individuals and prepare no room for scientific socialization. Decrease of social capital in higher education learners and graduates is a variable of a type of no need feeling toward society as they advance in their professional field of study (Zaker Salehi, 2008).

Taking all into consideration, for increase and improvement of social participation and trust among individuals especially the educated class in Iran, it is necessary to purposes and need assessment of higher education curriculums are developed according to components of social capital and the needs of society.

\section{References}

Alagheband, A. (2008). Educational planning and management. Tehran: Ravan press $\{$ in Persian\}

Bourdieu, P. (2003). action theory, scientific evidence and rationalchoice. translated: M, Modryha, Tehran:Nagsh- va- Negar press\{in Persian \}

Burnheim, C. (2004). Education and Social Capital, British Journal of ociology of Education, 25(5).

chalabi, M. (2007). Sociology of Order. Tehran: Nei Press. \{in Persian\}

Chalabi, M., \& Mobaraki, M. (2005). Analyze the Relationship between Social Capital and Crime in the Micro and Macro Levels in Iran. Iran sociology journal, No2. \{in Persian\}

Field, J. (2007). Social capital. translated: Ghafari, G. H. Ramezani, H. Tehran: Kavir 
press. $\{$ inPersian $\}$

Firouzabadi , S. A. (2005) Social capital and factors affecting its formation in Tehran. Iranian Journal of Sociology, 6, 143-152.\{in Persian \}

Flick, B., \& Williamson, K. (2005). Frontiers in Education. FIE Apos, Proceedings 35th Annual conference, 19-22 oct.

Grayson, P. (2004). Parental Networks, Social Closure, and Mathematics Learning. A Test of Coleman's Social Capital Explanation of School Effects. American Sociological Review, 64(5).

Inglehart, R. (2002). Modernization and post modernization. Cultural, Economic and Political change in 41 societies. Princeton: Princeton university press

Inglehart, R. (2003). Economic security and value Change, translated: Sh, Shafikhani, Social research journal No14. \{in Persian $\}$

Mehrmohammadi, M. (1388). curriculum Theories Approaches and erspectives. Tehran: samt $\&$ Behnashr press. $\{$ in Persian $\}$

Mohseni, M. (1998). Examining Social and Cultural Awareness, Attitudes, and Beliefs in Iran. Tehran: Ministry of Culture and Islamic Guidance press.\{in Persian\}

Mousavi Khameneh, M. (2005). Social capital and Social behavior. PHDThesis, Tehran: social sciences Tehran university. \{in Persian $\}$

Murphy, B., Holly, D. (2003). Crisis Management and Social Capital. ranslated: Hamid Reza Mohammadi. Journal of Social Welfare, Third Year \{in Persian \}

Park, H. (2006). The Role of trust on knowledge creation in a virtual university. A social capital perspective. Journal of Knowledge management practice, 7(4)

Piran, P., Moosavi, M. T., Shiyani, M. (2006). The concept and conceptualization of social capital based on Iran ondition. Social Welfare Journal, 23 \{in Persian\}

Putnam, R. (2005). Democracy and Civic traditions. translated: M. T., Delforooz, Tehran: Salam Journal Press. \{in Persian\}

Putnam, R. (2005). Social Capital: Measurement and Consequences. Kennedy School of Government, Harvard University.

Saif, A. A. (2009). Educational Psychology. Tehran: Agah press. \{in Persian\}

Sharepour, M. (2004). An Experimental Project of Social Capital in the Province of Mazandaran. Mazandaran University. \{in Persian\}

Totterman, A., \& Wulff, G. (2007). what a social capital perspective can bring to the understanding of information sharing in a university context. Ir Information Research, 12(4).

UNESCO. (1999). Global Statement of higher education for the next century. ranslated: Javdani, Tehran:Institute of Research and Planning in Higher Education 
Vahida, F. (1386). The relationship between social capital and social identity. social sciences of Isfahan university, Research journal Isfahan university, 2.\{in Persian\}

Woolcock, M. (2001). The Place of Social Capital in Understanding Social and Economic Outcomes. sumo:Canadian Journal of Policy Research, 2(1), 1-17.

Woolcock, M. (2008). Social capital and economic development toward a theoretical synthesis and policy framework. Theory and Society, 27.

Yarmohammadian, Mh. (2012). Curriculum Planning Principles. Tehran:Yadvar-e-ketab press. $\{$ in Persian $\}$

Zaker Salehi, G. R. (2008). The Paradox of Social Capital of Iranian Educated People. Survey and Study on the Relationship Between Higher Education and Social Capital in Iran. Journal of Engineering Education, 40(1), 25-51. Agah press. \{in Persian\}

\section{Copyright Disclaimer}

Copyright reserved by the author(s).

This article is an open-access article distributed under the terms and conditions of the Creative Commons Attribution license (http://creativecommons.org/licenses/by/3.0/). 